\title{
Studies of Energy-Linked Reactions
}

\author{
LOCALIZATION OF THE SITE OF ACTION OF TRIALKYLTIN IN \\ YEAST MITOCHONDRIA
}

\author{
By KELVIN CAIN and DAVID E. GRIFFITHS \\ Department of Molecular Sciences, University of Warwick, Coventry CV4 7AL, U.K.
}

(Received 15 September 1976)

\begin{abstract}
Ligand-binding studies with labelled triethyltin on yeast mitochondrial membranes showed the presence of high-affinity sites $\left(K_{\mathrm{D}}=0.6 \mu \mathrm{M} ; 1.2 \pm 0.3 \mathrm{nmol} / \mathrm{mg}\right.$ of protein $)$ and low-affinity sites $\left(K_{\mathrm{D}}>45 \mu \mathrm{M} ; 70 \pm 20 \mathrm{nmol} / \mathrm{mg}\right.$ of protein). The dissociation constant of the high-affinity site is in good agreement with the concentration of triethyltin required for inhibition of mitochondrial ATPase (adenosine triphosphatase) and oxidative phosphorylation. The high-affinity site is not competed for by oligomycin or venturicidin, indicating that triethyltin reacts at a different site from these inhibitors of oxidative phosphorylation. Fractionation of the mitochondrial membrane shows a specific association of the high-affinity sites with the ATP synthase complex. During purification of ATP synthase (oligomycin-sensitive ATPase) there is a 5-6-fold purification of oligomycin- and triethyltin-sensitive ATPase activity concomitant with a 7-9-fold increase in high-affinity triethyltin-binding sites. The purified yeast oligomycin-sensitive ATPase complex contains approximately six binding sites for triethyltin/mol of enzyme complex. It is concluded that specific triethyltin-binding sites are components of the ATP synthase complex, which accounts for the specific inhibition of ATPase and oxidative phosphorylation by triethyltin.
\end{abstract}

Trialkyltin compounds are potent inhibitors of oxidative phosphorylation (Aldridge \& Street, 1964; Sone \& Hagihara, 1964; Rose \& Aldridge, 1972) and inhibit dinitrophenol-stimulated ATPase activity as well as $\mathbf{P}_{\mathrm{i}}$-ATP-exchange activity, indicating a site of action in the ATP synthase complex similar to that of oligomycin and dicyclohexylcarbodi-imide. In addition, trialkyltin compounds catalyse a $\mathrm{Cl}^{-} / \mathrm{OH}^{-}$ exchange reaction in mitochondria and chloroplasts (Selwyn et al., 1970; Stockdale et al., 1970; Watling \& Selwyn, 1970; Dawson \& Selwyn, 1974), and facilitate swelling of mitochondria in $\mathrm{Cl}^{-}$-containing media. It is not known if the $\mathrm{Cl}^{-} / \mathrm{OH}^{-}$exchange (antiport) system in mitochondria represents a specific transport property of trialkyltin compounds, or whether it is the result of reactions with a specific site in the mitochondrial inner membrane which may be a component of the ATP synthase complex.

Interaction with the ATP synthase complex is indicated by the inhibition by trialkyltins of the oligomycin-sensitive ATPase from ox heart (Kagawa \& Racker, 1966; Tzagoloff et al., 1968; Byington, 1971) of $F_{1}$-ATPase. The demonstration that tributyltin $(1 \mathrm{nmol} / \mathrm{mg}$ of protein) induces respiratory control and lessens the proton permeability of

* Abbreviations: ATPase, adenosine triphosphatase; F1-ATPase, mitochondrial ATPase (Pullman et al., 1960). coupling-factor-deficient submitochondrial particles (Dawson \& Selwyn, 1975) indicates that trialkyltin compounds have a similar mode of action to oligomycin and dicyclohexylcarbodi-imide on hydrophobic protein subunits of the ATP synthase complex.

Previous studies on the binding of trialkyltin compounds to rat liver mitochondrial membranes (Aldridge \& Street, 1970) indicate the presence of high-affinity and low-affinity binding sites, and the dissociation constant for the high-affinity binding site is similar to the concentrations required to inhibit oxidative phosphorylation. However, the high-affinity site has not been specifically localized on any component of the oxidative-phosphorylation system. Biochemical-genetic studies (Lancashire \& Griffiths, 1975a) support the localization of the trialkyltin-interaction site in the oligomycin-sensitive ATPase, and genetic studies of cytoplasmic (mitochondrial) trialkyltin-resistant mutants indicate that the trialkyltin-interaction site involves a different protein component from that involved in the oligomycin-interaction site (Griffiths et al., 1975).

The present paper describes studies with triethyl$\left.{ }^{[113} \mathrm{Sn}\right]$ tin which localize most of the high-affinity triethyltin-binding sites in yeast mitochondria in the oligomycin-sensitive ATPase complex described by Tzagoloff et al. (1973). 


\section{Materials}

The source of many of the materials and reagents used has been described previously (Griffiths \& Houghton, 1974).

Hepes [4-(2-hydroxyethyl)-1-piperazine-ethanesulphonic acid] and Triton X-100 were from Sigma (London) Chemical Co., Kingston-upon-Thames, Surrey, U.K. Triethyl[ $\left.{ }^{113} \mathrm{Sn}\right]$ tin chloride $(8.6 \mathrm{Ci}$ / mmol) was from The Radiochemical Centre, Amersham, Bucks., U.K. Trialkyltin chlorides and triethyltin sulphate were obtained as previously described (Lancashire \& Griffiths, 1975a) and used as ethanolic solutions. Spectrophore dialysis membrane (mol.wt. cut-off 6000-7000) was from Raven Scientific, Haverhill, Suffolk, U.K., and washed for several hours in water before use. All other reagents were of A.R. grade.

\section{Methods}

Growth and isolation of yeast, isolation of yeast mitochondria, preparation and isolation of yeast submitochondrial particles, the assay of protein, ATPase activity and inhibitor sensitivity ( $I_{50}$ values) are essentially as described by Griffiths \& Houghton (1974).

The partially purified oligomycin-sensitive ATPase was prepared by extraction of yeast submitochondrial particles with $0.5 \%$ (w/v) Triton X-100 essentially as described by Tzagoloff \& Meagher (1971). This preparation is referred to as the Triton X-100 extract, and the residue after extraction is termed the Triton-extracted particles. Purified oligomycinsensitive ATPase was prepared from the Triton X-100 extract by density-gradient centrifugation as described by Tzagoloff \& Meagher (1971). Yeast submitochondrial particles depleted of $F_{1}$-ATPase and oligomycin-sensitivity-conferring protein were prepared by extraction with $\mathrm{NaBr}$ and $\mathrm{NH}_{3}$ as described by Tzagoloff (1971) and are referred to as depleted particles in the text.

Triethyl[113 $\mathrm{Sn}]$ tin was assayed by liquid-scintillation counting in a Packard 4325 scintillation counter. Samples were contained in $1 \mathrm{ml}$ of aqueous solution and added to $9 \mathrm{ml}$ of a Triton X-100-based scintillant solution [1 litre of toluene, 0.5 litre of Triton X-100, $7 \mathrm{~g}$ of 5-(4-biphenylyl)-2-(4-t-butylphenyl)-1-oxa-3,4diazole]. Standards were counted for radioactivity with each batch of samples. Under these conditions the efficiency of counting was $60 \%$.

\section{Binding studies with triethyl[ ${ }^{113}$ Sn]tin}

Binding of triethyltin to mitochondria and submitochondrial particles was carried out by incubating triethyl[ $\left.{ }^{113} \mathrm{Sn}\right]$ tin with $1-2 \mathrm{mg}$ of mitochondrial protein in $5.0 \mathrm{ml}$ of buffer $(0.5 \mathrm{M}$-sorbitol $/ 10 \mathrm{mM}$ Hepes/KOH, $\mathrm{pH} 7.5$ ) in cellulose nitrate centrifuge tubes at $5^{\circ} \mathrm{C}$ for $30 \mathrm{~min}$. Mitochondria and submitochondrial particles were separated by centrifugation at $100000 \mathrm{~g}$ in the $\mathbf{4 0 . 3}$ rotor of the Beckman ultracentrifuge for $30 \mathrm{~min}$ at $5^{\circ} \mathrm{C}$. Samples of the supernatant were taken for scintillation counting, and the remaining supernatant was discarded and the precipitate solubilized by leaving overnight in $1.0 \mathrm{ml}$ of $2 \%(w / v)$ Triton X-100. The supernatant and precipitate were assayed for radioactivity by scintillation counting to estimate the concentration of free and bound ligand. There was no significant binding of triethyl[ $\left.{ }^{113} \mathrm{Sn}\right]$ tin to the cellulose nitrate tubes.

Equilibrium-dialysis studies with detergent-dispersed oligomycin-sensitive ATPase were carried out in a multicavity micro-dialysis cell (cat. no. 6779-09; Cole-Parmer, Chicago, IL, U.S.A.) rotated at 20rev./min. The dialysis cell contained approx. $150 \mu \mathrm{g}$ of oligomycin-sensitive ATPase in $0.5 \mathrm{ml}$ of sucrose buffer $\left[0.36 \mathrm{M}\right.$-sucrose $/ 10 \mathrm{~mm}$-Tris $/ \mathrm{H}_{2} \mathrm{SO}_{4}$, pH7.5, containing $0.1 \%(w / v)$ Triton X-100]. The other chamber contained $0.5 \mathrm{ml}$ of the same buffer containing $0.4 \mu \mathrm{M}-0.4 \mathrm{mM}$-triethyl[ $\left.{ }^{113} \mathrm{Sn}\right]$ tin. Under these conditions there was no significant binding of triethyltin to the dialysis membrane or incubation chamber. Samples of both chambers of the dialysis cell were removed for scintillation counting after dialysis for $24 \mathrm{~h}$ at $5^{\circ} \mathrm{C}$. Control experiments showed complete equilibrium and recovery, also no decrease in the ATPase activity or modification of sensitivity to inhibitors over this period. The results from binding experiments were plotted by the procedure of Scatchard (1949) and analysed by trial and error.

\section{Results}

The yeast mitochondrial oligomycin-sensitive ATPase is readily solubilized from the mitochondrial inner membrane by $0.5 \%(\mathrm{w} / \mathrm{v})$ Triton $\mathrm{X}-100$, in contrast with the comparatively drastic conditions required to solubilize the oligomycinsensitive ATPase complex of heart and liver mitochondria, and retains sensitivity to oligomycin, venturicidin and triethyltin which approximates to that of the membrane-bound enzyme (Griffiths \& Houghton, 1974). This provides a suitable method for determining the association of high-affinity binding sites for triethyltin with components of the yeast mitochondrial membrane, particularly the oligomycin-sensitive ATPase.

Fig. 1 shows that a similar degree of sensitivity to triethyltin is observed in the oligomycin-sensitive ATPase in submitochondrial particles and the Triton X-100 extract, and a slightly modified sensitivity in purified oligomycin-sensitivity ATPase. Purified $\mathrm{F}_{1}$-ATPase exhibited less than $10 \%$ inhibition by triethyltin, even at $500 \mathrm{nmol} / \mathrm{mg}$ of protein. Triethyltin is not bound covalently, as the amount of inhibitor bound can be totally removed by three 


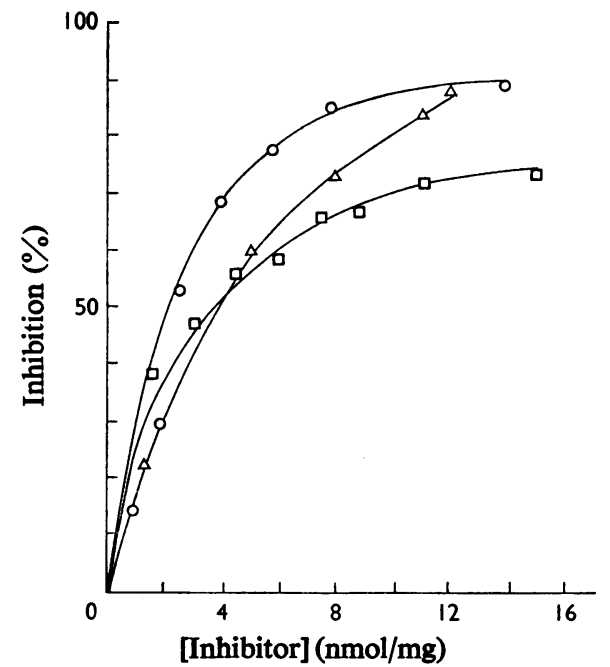

Fig. 1. Inhibition of detergent-solubilized oligomycin-sensitive ATPase and membrane bound oligomycin-sensitive ATPase by triethyltin

O, Submitochondrial particles (specific activity, $5 \mu \mathrm{mol} / \mathrm{min}$ per $\mathrm{mg}$ of protein); $\Delta$, Triton $\mathrm{X}-100$ extract (specific activity, $9 \mu \mathrm{mol} / \mathrm{min}$ per $\mathrm{mg}$ of protein); $\square$, purified oligomycin-sensitive ATPase (specific activity, $27 \mu \mathrm{mol} / \mathrm{min}$ per $\mathrm{mg}$ of protein). ATPase assays were carried out at $\mathrm{pH} 9.5$ at $30^{\circ} \mathrm{C}$ and $P_{1}$ release was measured as described by Griffiths \& Houghton (1974). The enzyme preparations used are described in the Methods section.

washes with binding medium, with restoration of ATPase activity.

Ligand-binding studies with triethyl[ $\left.{ }^{113} \mathrm{Sn}\right]$ tin and yeast mitochondrial particles show that there are two classes of binding site (Fig. 2), as shown by Aldridge \& Street (1970) for liver mitochondria. Analysis of the binding data indicates a class of high-affinity $\operatorname{sites}\left(K_{\mathrm{D}}=0.6 \pm 0.2 \mu \mathrm{M} ; 1.2 \pm 0.3 \mathrm{nmol} / \mathrm{mg}\right.$ of protein $)$ present in low concentration and a class of lowaffinity sites $\left(K_{\mathrm{D}}>45 \mu \mathrm{M} ; 70 \pm 20 \mathrm{nmol} / \mathrm{mg}\right.$ of protein) present in high concentration. The dissociation constant and concentration of high-affinity sites is in good agreement with the concentrations of triethyltin required for inhibition of mitochondrial ATPase, whereas the low-affinity sites probably represent nonspecific binding to membrane proteins and phospholipid.

Extraction of yeast submitochondrial particles with $0.5 \%(w / v)$ Triton X-100 removes oligomycinsensitive ATPase (triethyltin-sensitive ATPase), with a corresponding decrease in the number of highaffinity binding sites for triethyltin present in the Triton X-100-extracted particles (Fig. 2 and Table 1). The concentration of low-affinity binding sites in the
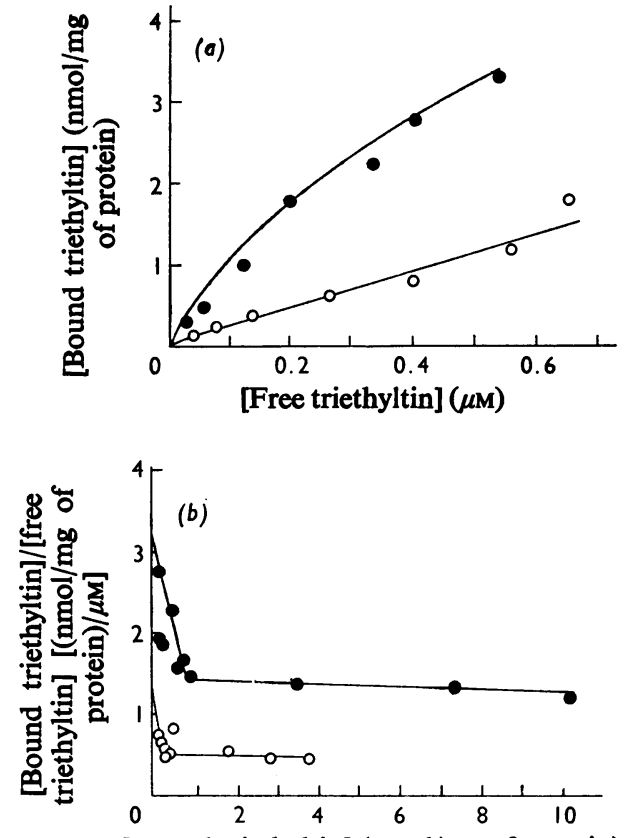

[Bound triethyltin] ( $\mathrm{nmol} / \mathrm{mg}$ of protein)

Fig. 2. Binding of triethyl[ $\left.{ }^{1{ }^{13}} \mathrm{Sn}\right]$ tin to particles and Triton $X$-100-extracted particles

(a) Amount bound plotted against free ligand concentration; (b) data analysed by the method of Scatchard (1949), with the bound/free ratio plotted against the amount bound. $\bullet$, Particles (no. of highaffinity sites $=0.9 \mathrm{nmol} / \mathrm{mg}, K_{\mathrm{D}}=0.43 \mu \mathrm{M}$; no. of low-affinity sites $\left.=60 \mathrm{nmol} / \mathrm{mg}, \quad K_{\mathrm{D}}=40 \mu \mathrm{M}\right)$. $\circ$, Triton X-100-extracted particles (no. of highaffinity sites $=0.2 \mathrm{nmol} / \mathrm{mg}, K_{\mathrm{D}}=0.25 \mu \mathrm{M}$; no. of lowaffinity sites $=50 \mathrm{nmol} / \mathrm{mg}, K_{\mathrm{D}}=80 \mu \mathrm{M}$ ).

Triton X-100-extracted particles is not markedly affected, and it appears that most of the high-affinity sites are extracted with the oligomycin-sensitive ATPase into the Triton X-100 extract. However, up to $30 \%$ of the high-affinity sites are retained in Triton-extracted particles, which suggests that all of the high-affinity sites are not in tight association with the oligomycin-sensitive ATPase complex.

Association of the high-affinity binding sites with oligomycin-sensitive-ATPase is seen on examination of the ligand-binding properties of the purified complex (Fig. 3). Only one class of binding site is found, of relatively high affinity $\left(K_{\mathrm{D}}=6-7 \mu \mathrm{M} ; 11-12 \mathrm{nmol} /\right.$ $\mathrm{mg}$ of protein), and there is no evidence for the lowaffinity binding sites $\left(K_{\mathrm{D}}>45 \mu \mathrm{M}\right)$ found in mitochondrial particles. There is also an increase in the concentration of high-affinity sites, which is consistent with the degree of purification of the oligomycinsensitive ATPase from sub-mitochondrial particles. 
Table 1. Binding of triethyltin to mitochondrial oligomycin-sensitive ATPase

Triethyltin binding to various mitochondrial preparations was determined as described in the Methods section. The results are expressed where appropriate as means \pm S.D.

\begin{tabular}{|c|c|c|c|c|c|c|}
\hline \multirow[b]{2}{*}{ Preparation } & \multirow[b]{2}{*}{$\begin{array}{c}\text { No. of } \\
\text { observations }\end{array}$} & \multicolumn{2}{|c|}{ High-affinity sites } & \multicolumn{2}{|c|}{ Low-affinity sites } & \multirow{2}{*}{$\begin{array}{c}\text { Specific activity of } \\
\text { triethyltin-sensitive } \\
\text { ATPase }(\mu \mathrm{mol} / \mathrm{min} \text { per } \mathrm{mg})\end{array}$} \\
\hline & & $\begin{array}{c}K_{\mathrm{D}} \\
(\mu \mathrm{M})\end{array}$ & $\begin{array}{c}\begin{array}{c}\text { No. of sites } \\
(\mathrm{nmol} / \mathrm{mg})\end{array} \\
\text {. }\end{array}$ & $\begin{array}{c}K_{\mathrm{D}} \\
(\mu \mathrm{M})\end{array}$ & $\begin{array}{c}\begin{array}{c}\text { No. of sites } \\
(\mathrm{nmol} / \mathrm{mg})\end{array} \\
\text { (n) }\end{array}$ & \\
\hline $\begin{array}{l}\text { articles } \\
\text { rriton X-100 extracted } \\
\text { particles* }\end{array}$ & $\begin{array}{l}4 \\
4\end{array}$ & $\begin{array}{l}0.6 \pm 0.2 \\
0.3 \pm 0.1\end{array}$ & $\begin{array}{l}1.2 \pm 0.3 \\
0.35 \pm 0.2\end{array}$ & $\begin{array}{l}45 \pm 9 \\
76 \pm 15\end{array}$ & $\begin{array}{c}70 \pm 20 \\
55 \pm 9\end{array}$ & $\begin{array}{l}5.7 \pm 0.5 \\
1.2 \pm 0.2\end{array}$ \\
\hline $\begin{array}{l}\text { ligomycin-sensitive } \\
\text { ATPase }\end{array}$ & 2 & 6.9 & 11.9 & - & - & 27 \\
\hline Depleted particles & 1 & 1.2 & 4.5 & 41 & 102 & 0 \\
\hline
\end{tabular}
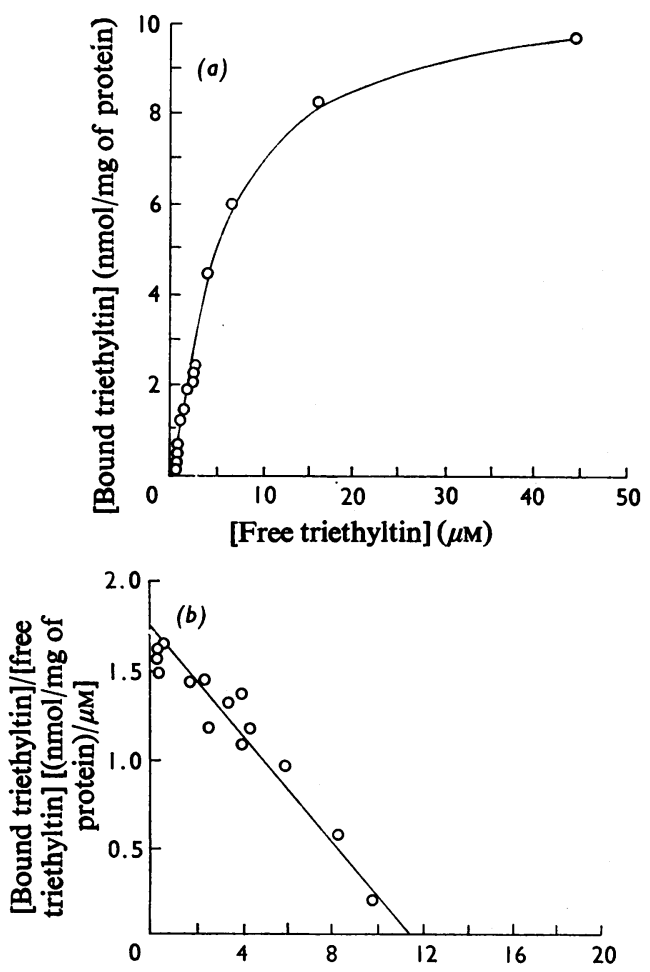

[Bound triethyltin] (nmol/mg of protein)

Fig. 3. Binding of triethyl[ $\left.{ }^{113} \mathrm{Sn}\right]$ tin to purified oligomycin-sensitive ATPase

(a) Amount bound plotted against free ligand concentration; $(b)$ data analysed by the method of Scatchard (1949) with bound/free ratio plotted against the amount bound. $K_{\mathrm{D}}=6.9 \mu \mathrm{M}$, no. of sites = $11.6 \mathrm{nmol} / \mathrm{mg}$.

Possible reasons for the tenfold decrease in affinity for triethyltin are discussed below, but the results clearly establish an association of high-affinity sites for triethyltin with the oligomycin-sensitive ATPase.
That the high-affinity binding sites for triethyltin are associated with the hydrophobic subunits of the oligomycin-sensitive ATPase is shown in experiments where the $F_{1}$-ATPase and oligomycin-sensitivityconferring protein are preferentially removed from the membrane by $\mathrm{NaBr} / \mathrm{NH}_{3}$ extraction (Griffiths \& Houghton, 1974), leaving most of the hydrophobic subunits of the oligomycin-sensitive ATPase in the depleted particles. $\mathrm{NaBr} / \mathrm{NH}_{3}$ extraction does not remove the high-affinity binding sites (Fig. 4 and Table 1). In fact, there is an increase in the concentration of high-affinity sites, reflecting the increased concentration of hydrophobic subunits of the oligomycin-sensitive ATPase complex present in the depleted particles.

The effect of $\mathrm{pH}$ on binding of triethyltin to particles was investigated, as this may give some indication of the $\mathrm{p} K_{\mathrm{a}}$ values of functional groups involved in binding. Aldridge \& Rose (1969) have proposed that two histidine residues per binding site are involved as a result of studies of the effect of $\mathrm{pH}$ on ADP-stimulated respiration, which is supported by studies of triethyltin-binding sites on a model system. Table 2 shows that there is little change in binding of triethyltin in the $\mathrm{pH}$ range 6.0-7.5 and a decrease in binding above pH7.5. Similar results have been reported by Dawson \& Selwyn (1974), and the involvement of histidine residues of the triethyltin-binding site remains to be established.

Oligomycin and venturicidin have a similar mode of action to triethyltin (Sone \& Hagihara, 1964; Stockdale et al., 1970) and it is assumed that they have a similar site of action. However, significant differences in the mode of action of triethyltin have been noted by Aldridge \& Street (1971), and biochemicalgenetic studies in this laboratory (Lancashire \& Griffiths $1975 a, b)$ indicate that the resistance determinants that specify triethyltin resistance, and hence the components of the binding site, are different from those which specify oligomycin- and venturicidin-resistance. 

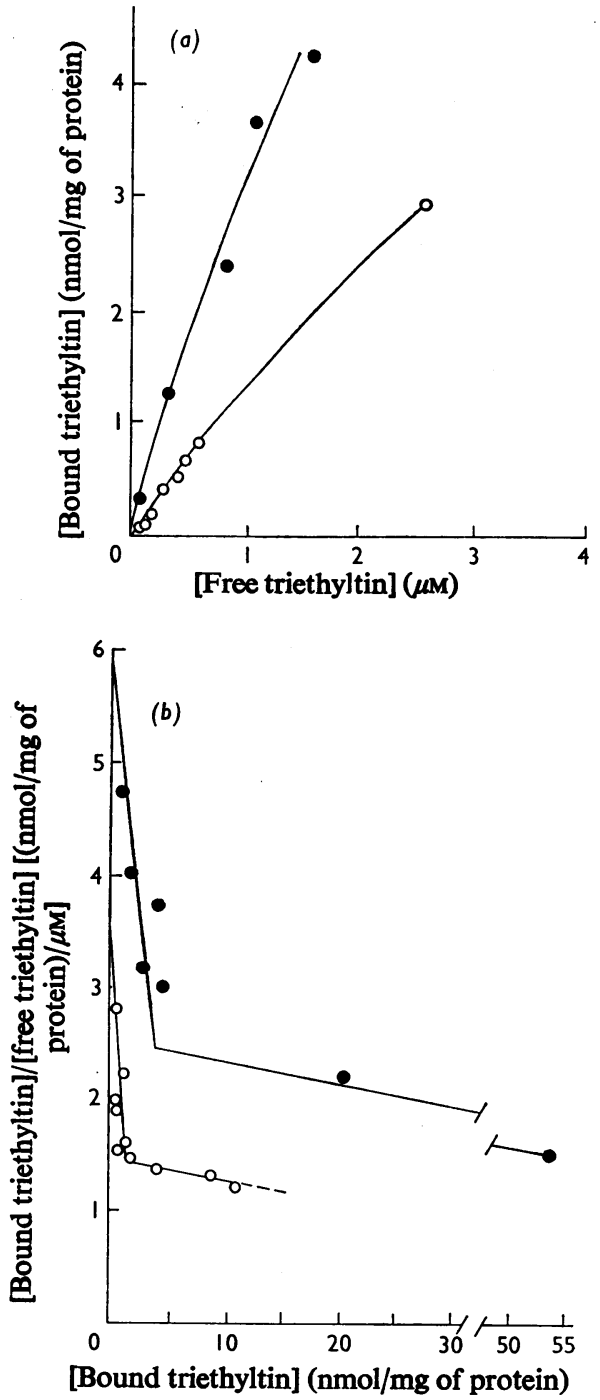

Fig. 4. Binding of triethyl[ ${ }^{13}$ Sn]tin to depleted particles (a) Amount bound plotted against free ligand concentration; $(b)$ data analysed by the method of Scatchard (1949) with the bound/free ratio plotted against the amount bound. $\bullet$, Depleted particles (no. of high-affinity sites $=4.5 \mathrm{nmol} / \mathrm{mg}, K_{\mathrm{D}}=1.2 \mu \mathrm{M}$ ). $\mathrm{O}$, Control, i.e. binding to particles (no. of highaffinity sites $=0.9 \mathrm{nmol} / \mathrm{mg}, K_{\mathrm{D}}=0.43 \mu \mathrm{M} ;$ no. of low-affinity sites $\left.=60 \mathrm{nmol} / \mathrm{mg}, K_{\mathrm{D}}=40 \mu \mathrm{M}\right)$.

Fig. 5 shows that oligomycin and venturicidin have no effect on the binding of triethyltin to mitochondrial particles even at concentrations 10 times higher than that at which they cause $50 \%$ inhibition of ATPase activity ( $I_{50}$ value), and support the conclusion that triethyltin binds at a separate and distinct binding site.

Vol: 162
Table 2. Binding of triethyltin to high-and low-affinity sites Binding of particles was measured as described in the Methods section. In (a) particles were incubated with $0.42 \mathrm{nmol}$ of triethyltin/mg of protein; this titrates predominantly high-affinity sites. In (b) particles were incubated with $42 \mathrm{nmol}$ of triethyltin/mg of protein, thus titrating the low-affinity sites. The results are expressed in terms of the bound/free ratio described by Scatchard (1949).

$\begin{array}{lll}\text { pH } & \overbrace{(a)} & (b) \\ 6.0 & 2.7 & 1.7 \\ 6.8 & 2.7 & 1.4 \\ 7.0 & 2.6 & 1.3 \\ 7.5 & 2.4 & 1.25 \\ 8.0 & 2.1 & 1.1 \\ 8.5 & 1.4 & 0.8\end{array}$
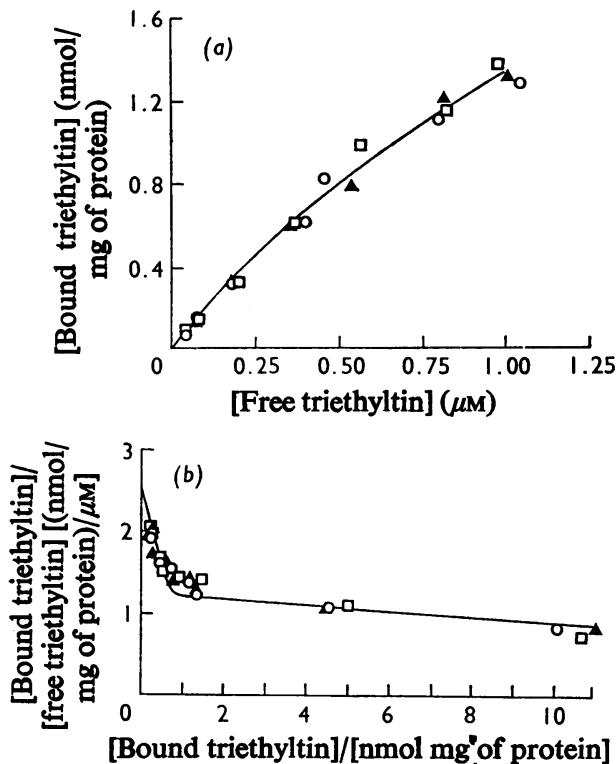

Fig. 5. Effect of oligomycin and venturicidin on triethyl$\left[{ }^{113} \mathrm{Sn}\right]$ tin binding to particles

Particles were preincubated for $30 \mathrm{~min}$ with inhibitors before carrying out triethyl[ $\left.{ }^{113} \mathrm{Sn}\right]$ tin binding. Analysis of binding data was as described for Fig. 2. $\mathrm{O}$, Control, i.e. no inhibitor; $\Delta, 2 \mu \mathrm{g}$ of venturicidin/ mg; $\square, 10 \mu \mathrm{g}$ of oligomycin/mg. No. of high-affinity binding sites $=1.0 \mathrm{nmol} / \mathrm{mg}, K_{\mathrm{D}}=0.5 \mu \mathrm{M}$; no. of low-affinity binding sites $=61 \mathrm{nmol} / \mathrm{mg}, K_{\mathrm{D}}=50 \mu \mathrm{M}$.

\section{Discussion}

The yeast mitochondrial inner membrane has been shown to have high-affinity binding sites and lowaffinity binding sites for triethyltin compounds, as shown by Aldridge \& ${ }^{-}$Street (1970) for liver mito- 
chondria. The dissociation constant $\left(K_{D}\right)$ for the highaffinity binding site is of the required value to explain inhibition of ATPase and oxidative phosphorylation by triethyltin (Table 1). Extraction of the highaffinity sites concomitant with extraction of the oligomycin-sensitive ATPase complex from the mitochondrial membrane indicates a specific association with the oligomycin-sensitive ATPase complex and thus locates the site of inhibition of oxidative phosphorylation on a component of the complex.

Table 1 shows that there is a 5-6-fold degree of purification with respect to oligomycin- and triethyltin-sensitive ATPase activity concomitant with a 7-9-fold increase in high-affinity triethyltin-binding sites. This indicates that a specific stoicheiometry is maintained during the purification procedure. Assuming that the $F_{1}$-ATPase represents $10 \%$ of the membrane protein and thus a content of approx. $0.2-0.3 \mathrm{nmol}$ of $\mathrm{F}_{1}$-ATPase $/ \mathrm{mg}$ of membrane protein, a value of approx. 5-6 binding sites per oligomycin-sensitive ATPase complex can be calculated. A similar stoicheiometry is obtained in the purified oligomycin-sensitive ATPase complex on the basis of a mol.wt. of 486000 (Tzagoloff \& Meagher, 1971). The high-affinity site in the purified oligomycin-sensitive ATPase has a higher $K_{\mathrm{D}}$ value $(6.9 \mu \mathrm{M})$ than that of the membrane-bound enzyme $\left(K_{\mathrm{D}}=0.6 \mu \mathrm{M}\right)$, and this is also reflected in an increase in the measured $I_{50}$ value for inhibition by triethyltin (Fig. 1). This is probably due to a conformational change in the lipid-depleted enzyme caused by its removal from the highly ordered hydrophobic lipid-enriched membrane environment. The 25$30 \%$ of high-affinity binding sites which remain in the membrane with unextracted ATPase (Table 1) probably represent tightly bound oligomycinsensitive ATPase or oligomycin-sensitive ATPase that has been modified during the extraction procedure.

Trialkyltins do not inhibit $\mathbf{F}_{1}$-ATPase, and extraction of $F_{1}$-ATPase, and the oligomycin-sensitivityconferring protein (Fig. 4) does not remove the high-affinity binding sites from the membrane. These results indicate that the high-affinity binding site is not associated with components of $F_{1}$-ATPase, but indicate a specific association with hydrophobic components of the membrane. These components are also specific components of the intact functional oligomycin-sensitive ATPase complex, which in yeast mitochondria is readily extractable by Triton X-100 (Tzagoloff \& Meagher, 1971). It has been demonstrated previously that the yeast oligomycin-sensitive ATPase complex contains the sensitivity sites for oligomycin, venturicidin, triethyltin and dicyclohexylcarbodi-imide (Griffiths \& Houghton, 1974), and biochemical-genetic studies indicate that at least three polypeptide species are involved (Griffiths, 1975). The retention of inhibitor-sensitivity in a detergent-dispersed oligomycin-sensitive ATPase complex of defined subunit composition would indicate that this complex represents a functional entity which is integrated into the oxidativephosphorylation complex of the mitochondrial inner membrane.

This work was supported by grants from the Science Research Council and the Tin Research Institute.

\section{References}

Aldridge, W. N. \& Rose, M. S. (1969) FEBS Lett. 4, 61

Aldridge, W. N. \& Street, B. W. (1964) Biochem. J. 91, 287-297

Aldridge, W. N. \& Street, B. W. (1970) Biochem. J. 118, 171-179

Aldridge, W. N. \& Street, B. W. (1971) Biochem. J. 124, 221-234

Byington, K. H. (1971) Biochem. Biophys. Res. Commun. 42, 16-22

Dawson, A. P. \& Selwyn, M. J. (1974) Biochem. J. 138, 349-357

Dawson, A. P. \& Selwyn, M. J. (1975) Biochem. J. 152, 333-339

Griffiths, D. E. (1975) in Genetics and Biogenesis of Mitochondria and Chloroplasts (Birky, C. W., Jr., Perlman, P. S. \& Byers, T. J., eds.), pp. 117-135, Ohio State University Press, Columbus

Griffiths, D. E. \& Houghton, R. L. (1974) Eur. J. Biochem. 46, 157-167

Griffiths, D. E., Houghton, R. L., Lancashire, W. E. \& Meadows, P. A. (1975) Eur. J. Biochem. 51, 393-402

Kagawa, Y. \& Racker, E. (1966) J. Biol. Chem. 241, 2461-2466

Lancashire, W. E. \& Griffiths, D. E. (1975a) Eur. J. Biochem. 51, 377-392

Lancashire, W. E. \& Griffiths, D. E. (1975b) Eur. J. Biochem. 51, 403-413

Pullman, M. E., Penefsky, H. S., Datta, A. \& Racker, E. (1960) J. Biol. Chem. 235, 3322-3329

Rose, M. S. \& Aldridge, W. N. (1972) Biochem. J. 127, 51-59

Scatchard, G. (1949) Ann. N.Y. Acad. Sci. 51, 660-672

Selwyn, M. J., Dawson, A. P., Stockdale, M. \& Gains, N. (1970) Eur. J. Biochem. 14, 120-126

Sone, N. \& Hagihara, B. (1964) J. Biochem. (Tokyo) 56, 151-156

Stockdale, M., Dawson, A. P. \& Selwyn, M. J. (1970) Eur. J. Biochem. 15, 342-351

Tzagoloff, A. (1971) J. Biol. Chem. 246, 3050-3056

Tzagoloff, A. \& Meagher, P. (1971) J. Biol. Chem. 246, 7328-7336

Tzagoloff, A., Maclennan, D. \& Byington, K. H. (1968) Biochemistry 7, 1596-1602

Tzagoloff, A., Rubin, M. S. \& Sierra, M. F. (1973) Biochim. Biophys. Acta 301, 71-104

Watling, A. S. \& Selwyn, M. J. (1970) FEBS Lett. 10, 139-142 